\title{
Analisis Sikap Peduli Lingkungan Pada Siswa Kelas VI Sekolah Dasar di Kota Ruteng
}

\author{
Yosef Firman Narut, Mikael Nardi \\ narutyosef@gmail.com, mikaelnardi@gmail.com \\ FKIP Universitas Katolik Indonesia Santu Paulus Ruteng
}

The Analysis On The Sixth Grade Students' Environmental Care At Elementary School In Ruteng

\begin{abstract}
This study mainly aims to describe and analyze the environmental cares of the $6^{\text {th }}$ class elementary school students in Ruteng. Three attitude components were assessed: cognition, affection, and conation components. A descriptive qualitative research were designed through survey method which involved the $6^{\text {th }}$ grade students as the population from elementary schools in Ruteng. Simple random sampling was employed to determine four elementary schools as samples; those schools were SDK Ruteng 1, SDK Ruteng 3, SDI Wae Ri'i, and SDI Karot. The data were collected through a questionnaire while the data analysis technique was based on Miles and Huberman models which covers reduction, data display, and conclusion / verification. The data were validated in triangulation test, namely: theory triangulation, data triangulation, and expert triangulation. The results of the study showed that the average score of environmental care attitudes of the $6^{\text {th }}$ students' in Ruteng was 77.81 in a good category. Meanwhile, the average of attitude score components covering the cognition component was 80.3 in the excellent category, affection component was 80.05 in the excellent category, and the conation component was 73.1 in the good category. Based on four elementary school samples, those results were consistently found and the environmental care score on the conation component was lower than the other two components. This indicates that cognitive and affective factors do not necessarily affect on students' conations. Even though the students have awareness (cognition) and feelings (affection) related to the surrounding environmental problems, these are not visible in their daily behavior (conation).
\end{abstract}

Keywords: Attitude, Environmental, Environmental Care

Received date: 25 Juni $2019 \quad$ Revised date: 3 September 2019

Accepted date: 20 September 2019

\section{PENDAHULUAN}

Isu global tentang lingkungan menjadi hal yang sangat sering terdengar dimasa kini; dimana banyak sekali kerusakan lingkungan yang terjadi akibat pembalakan liar dan penggunaan sumber daya alam (SDA) secara berlebihan, tanpa ada konservasi yang berkelanjutan. Kemajuan teknologi yang pesat di berbagai bidang telah menimbulkan dampak pada lingkungan, baik yang berdampak positif maupun negatif. Salah satu dampak negatif adalah terjadinya kerusakan lingkungan hidup, sehingga berakibat pada penurunan kualitas lingkungan hidup (Nasution, 2016).

Faktor lingkungan sangat mempengaruhi kualitas kehidupan manusia. Demikian juga sebaliknya, berbagai aktivitas dan sikap manusia juga turut mempengaruhi kualitas lingkungan itu sendiri. Kehidupan yang saling ketergantungan antara keduanya, menempatkan manusia sebagai subjek utama yang mengambil manfaat dari SDA untuk menunjang kelangsungan hidupnya. Posisi manusia sebagai subjek dalam pemanfaatan SDA, terkadang membuat manusia lupa diri karena didorong adanya keinginan untuk memenuhi kebutuhannya. Proses pembangunan yang hanya mengejar pertumbuhan dan pemerataan ekonomi, tanpa mempertimbangkan aspek keberlanjutan lingkungan hidup, tentunya dapat menimbulkan degradasi atau penurunan kualitas lingkungan.

Selain proses pembangunan yang tidak berkelanjutan dan faktor alam; sikap dan gaya hidup konsumtif manusia juga mengakibatkan degradasi lingkungan. Intergovernmental Panel on Climate Change (IPCC) pada 2007 dalam kajiannya menjelaskan, aktivitas manusia merupakan salah satu penyebab utama meningkatnya konsentrasi gas rumah kaca di atmosfer bumi, yang pada akhirnya turut 
menyumbang terjadinya global warming dan perubahan iklim. Beberapa aktivitas manusia tersebut antara lain penggunaan transportasi yang tidak ramah lingkungan, penggunaan energi berbahan bakar fosil, pembalakan liar (illegal logging), pengalihan fungsi hutan menjadi lahan perkebunan, dan lain sebagainya.

Dalam kehidupan sehari-hari, seseorang dihadapkan pada berbagai pilihan bersikap, baik yang merusak maupun yang bermanfaat untuk lingkungan. Untuk mendukung sikap kepedulian manusia terhadap lingkungan, maka melalui lembaga pendidikan, perlu diberikan pemahaman tentang pentingnya menjaga kelestarian lingkungan hidup (Badan Pusat Statistik, 2014). Pemahaman yang utuh tentang lingkungan, diharapkan dapat mengubah prilaku masyarakat agar lebih peduli terhadap lingkungan sekitarnya.

Peduli lingkungan merupakan sikap dan tindakan yang selalu berupaya mencegah kerusakan pada lingkungan alam di sekitarnya, dan mengembangkan upaya-upaya untuk memperbaiki kerusakan alam yang sudah terjadi (Asmani, 2013). Sikap ini perlu dibentuk menjadi suatu kebiasaan yang baik untuk generasi muda (Rahmawati \& Suwanda, 2015); sehingga, perlu dikembangkan sejak dini pada siswa SD sebagai calon generasi masa depan, yang akan bertindak sebagai agen aktif perubahan. Pembiasaan yang baik ini, dapat dilakukan melalui pembelajaran yang berwawasan lingkungan hidup.

Pembelajaran yang dikaitkan dengan sikap peduli lingkungan, diharapkan mampu menyadarkan siswa agar memiliki kepedulian pada alam dan lingkungan sekitar (Zuchdi \& Darmiyati, 2011). Hal ini sejalan dengan pendapat Kose (2011) bahwa, salah satu hasil pembelajaran yang dikaitkan dengan sikap peduli lingkungan adalah mengubah sikap siswa agar lebih positif terhadap lingkungan. Membina sikap peduli lingkungan dapat dilakukan dengan membiasakan siswa membuang sampah berdasarkan jenis sampah, merawat tanaman, menjaga kebersihan kelas dan sekolah, dan sebagainya (Yunansah \& Herlambang, 2017).

Hasil penelitian Rohweder (2004), menyatakan bahwa sikap peduli lingkungan siswa masih dinyatakan rendah karena beberapa faktor yang salah satunya adalah niat untuk mengetahui dan mempelajari masalah-masalah lingkungan. Dengan faktor guru sebagai pendidik harus menginformasikan dan menyadarkan bahwa pemahaman tentang lingkungan harus menjadi dasar dari sikap untuk dapat memecahkan maslah-masalah lingkungan (Nasution, 2016).

Berdasarkan uraian di atas, peneliti telah melakukan penelitian tentang analisis sikap peduli lingkungan pada siswa SD kelas VI di Kota Ruteng. Penentuan tempat penelitian didasari alasan bahwa, permasalahan tentang lingkungan menjadi salah satu isu penting di Kota Ruteng. Ruteng menjadi satu dari empat kota kecil dengan nilai paling rendah pada program penilaian Adipura periode 2017 - 2018. Kementerian Lingkungan Hidup dan Kehutanan mengkategorikan Kota Ruteng sebagai salah satu kota kecil terkotor di Indonesia (Aris, 2019). Selain itu, siswa SD kelas VI berada pada fase peralihan perkembangan intelektual dari tahap operasional konkrit ke tahap operasional formal; sehingga, kajian terhadap sikap peduli lingkungan siswa SD kelas VI di Kota Ruteng dipandang penting untuk diketahui, karena para siswa merupakan calon generasi masa depan yang akan bertindak sebagai agen aktif perubahan.

\section{KAJIAN PUSTAKA}

\section{Lingkungan}

Undang-Undang No 32 Tahun 2009 mendefinisikan lingkungan hidup sebagai kesatuan ruang dengan semua benda, daya, keadaan, dan makhluk hidup, termasuk manusia dan sikapnya, yang mempengaruhi alam itu sendiri, kelangsungan perikehidupan, dan kesejahteraan manusia serta makhluk hidup lain. Lingkungan adalah semua faktor luar, fisik, dan biologis yang secara langsung berpengaruh terhadap ketahanan hidup, pertumbuhan, perkembangan, dan reproduksi organisme, sedangkan yang dimaksud lingkungan hidup adalah kesatuan ruang dengan semua benda, daya, keadaan, dan makhluk hidup, termasuk di dalamnya manusia dan sikapnya, yang mempengaruhi kelangsungan perikehidupan dan kesejahteraan manusia serta makhluk hidup lainnya (Mustofa, 2010). Lebih lanjut, Supardi (2004) menjelaskan, lingkungan hidup adalah semua benda hidup dan mati serta seluruh kondisi yang ada di dalam ruang yang kita tempati. Jadi, dapat disimpulkan bahwa lingkungan hidup adalah segala sesuatu yang ada di sekitar manusia, baik itu komponen biotik maupun abiotik yang saling berinteraksi membentuk hubungan timbal balik. 
Merujuk pada pengertian di atas, secara garis besar ada dua komponen lingkungan, yaitu abiotik dan biotik. Komponen abiotik meliputi segala benda mati dan keadaan fisik yang ada di sekitar individuindividu, misalnya: tanah, bebatuan, air, udara, sinar matahari, dan lain sebagainya. Sedangkan, komponen biotik meliputi segala makhluk hidup yang ada di sekitar individu baik manusia, hewan, tumbuh-tumbuhan, dan mikroorganisme. Setiap komponen ini saling berinteraksi membentuk hubungan timbal balik (Supardi, 2004).

\section{Sikap Peduli Lingkungan}

Sikap adalah perbuatan atau pernyataan evaluatif sebagai respon terhadap suatu objek atau peristiwa. Sedangkan, peduli adalah tindakan keberpihakan terhadap suatu objek atau peristiwa. Menurut Asmani (2013), sikap peduli lingkungan berupa tindakan yang selalu berupaya mencegah kerusakan pada lingkungan alam sekitarnya, selain itu mengembangkan upaya-upaya untuk memperbaiki kerusakan alam yang sudah terjadi. Lebih lanjut, Zuchdi (2011) menjelaskan, peduli lingkungan adalah sikap dan tindakan yang selalu berupaya mencegah kerusakan pada lingkungan alam di sekitarnya, dan mengembangkan upaya-upaya untuk memperbaiki kerusakan alam yang sudah terjadi. Jadi dapat disimpulkan, sikap peduli lingkungan adalah perbuatan atau pernyataan yang menunjukan keberpihakan terhadap kelestarian lingkungan.

Sikap peduli lingkungan harus dibangun di atas tiga komponen penting dari sikap itu sendiri. Menurut Mar'at (2008), tiga komponen penting tersebut, yaitu: 1) Komponen kognisi (kesadaran), komponen yang berhubungan dengan keyakinan, ide dan konsep; 2) Komponen afeksi (perasaan), komponen yang menyangkut kehidupan emosional seseorang; dan 3) Komponen konasi (perilaku), komponen yang merupakan kecenderungan bertingkah laku. Jadi, sikap peduli lingkungan merupakan perilaku yang muncul atas dasar kesadaran dan perasaan terhadap lingkungan.

\section{Pembelajaran yang Berorientasi Sikap Peduli Lingkungan}

Perilaku peduli lingkungan tidak hanya dibiasakan dalam lingkungan keluarga, tetapi juga harus ditumbuhkembangkan dalam sistem pendidikan, misalnya SD. Naim (2012) berpendapat bahwa, sekolah seharusnya menyusun metode yang efektif karena peduli lingkungan merupakan salah satu karakter penting yang seyogyanya dimiliki secara luas oleh setiap orang, khususnya para siswa yang menempuh jenjang pendidikan.

Pembelajaran yang dikaitkan dengan perilaku peduli lingkungan diharapkan mampu menyadarkan siswa agar memiliki kepedulian pada alam dan lingkungan sekitar. Membina sikap peduli lingkungan dapat dilakukan dengan membiasakan siswa membuang sampah berdasarkan jenis sampah, merawat tanaman, menjaga kebersihan kelas dan sekolah, dan sebagainya.

Pembelajaran yang berorientasi sikap peduli lingkungan merupakan salah satu alternatif untuk mengembalikan semua kesadaran peduli lingkungan melalui jalur formal. Membangun kesadaran terhadap lingkungan erat kaitannya dengan membangun budaya atau karakter itu sendiri. Artinya, diperlukan waktu yang lama untuk menjadikan budaya cinta lingkungan menjadi karakter sebuah bangsa (Muslich, 2011). Hal ini sejalan dengan pendapat Kose (2011) bahwa, salah satu hasil pembelajaran yang dikaitkan dengan sikap peduli lingkungan adalah mengubah sikap siswa agar lebih positif terhadap lingkungan. Membina sikap peduli lingkungan dapat dilakukan dengan membiasakan siswa membuang sampah berdasarkan jenis sampah, merawat tanaman, menjaga kebersihan kelas dan sekolah, dan sebagainya (Yunansah \& Herlambang, 2017).

\section{METODE PENELITIAN}

Pendekatan penelitian yang digunakan dalam penelitian ini adalah kualitatif dengan jenis deskriptif. Metode penelitian dilakukan secara survei. Waktu pelaksanaan penelitian berlangsung pada bulan April 2018 pada tahun ajaran 2018/2019. Populasi dalam penelitian ini adalah seluruh siswa SD kelas VI di Kota Ruteng berjumlah 760an yang tersebar pada 22 SD. Teknik pengambilan sampel secara simple random sampling dengan empat SD ditetapkan sebagai sampelnya, yakni SDK Ruteng 1, SDK Ruteng 3, SDI Wae Ri'i, dan SDI Karot.

Teknik pengumpulan data dilakukan secara non tes dengan menggunakan angket berupa kuesioner untuk mengukur sikap peduli lingkungan pada siswa (Lampiran 1). Penilaian instrumen angket menggunakan skala likert. Data hasil angket diolah dan dilakukan analisis secara deskriptif. Peneliti menggunakan teknik analisis data berdasarkan model Miles dan Huberman yang terdiri dari tiga alur kegiatan, yaitu: reduksi data, penyajian data, dan penarikan kesimpulan/verifikasi (Miles \& 
Huberman, 1992). Keabsahan data dalam penelitian dicek dengan menggunakan uji triangulasi. Penelitian ini menggunakan tiga jenis triangulasi/ konfirmasi temuan, yaitu: triangulasi teori, triangulasi data, dan triangulasi pakar (Moleong, 2007).

Skor sikap peduli lingkungan dihitung menggunakan rumus:

$$
=\frac{\text { Skor yang didapat }}{\text { Skor maksimal }} \times 100
$$

Penentuan kriteria sikap peduli lingkungan mengacu pada Tabel 1 berikut ini.

Tabel 1. Kriteria Sikap Peduli Lingkungan

\begin{tabular}{ccc}
\hline No & Skor Nilai & Kriteria \\
\hline 1 & $<60$ & Kurang \\
\hline 2 & $60-70$ & Cukup \\
\hline 3 & $>70-80$ & Baik \\
\hline 4 & $>80$ & Sangat Baik \\
\hline & & (Mahita, 2018)
\end{tabular}

\section{HASIL PENELITIAN DAN PEMBAHASAN}

\section{Hasil Penelitian}

Data hasil penyebaran angket sikap peduli lingkungan pada sampel siswa SD kelas VI di Kota Ruteng, ditampilkan hasilnya pada Tabel 2 berikut ini.

Tabel 2. Rekapitulasi Skor Sikap Peduli Lingkungan

\begin{tabular}{|c|c|c|c|c|c|}
\hline \multirow[t]{2}{*}{ No } & \multirow{2}{*}{$\begin{array}{c}\text { Nama } \\
\text { Sekolah }\end{array}$} & \multicolumn{3}{|c|}{$\begin{array}{l}\text { Komponen Sikap } \\
\text { Peduli Lingkungan }\end{array}$} & \multirow[t]{2}{*}{ Rata-rata } \\
\hline & & $\mathbf{A}$ & B & $\mathbf{C}$ & \\
\hline 1 & SDK Ruteng 1 & 85,4 & 85,3 & 75,5 & 82,07 \\
\hline 2 & SDK Ruteng 3 & 87,3 & 84,5 & 74,7 & 82,17 \\
\hline 3 & SDI Wae Ri’i & 73,5 & 74,9 & 71,9 & 73,43 \\
\hline 4 & SDI Karot & 74,9 & 75,5 & 70,3 & $\mathbf{7 3 , 5 7}$ \\
\hline & Rata-rata & 80,3 & 80,05 & 73,1 & 77,81 \\
\hline
\end{tabular}

Keterangan:
A : Komponen Kognisi
B : Komponen Afeksi
C : Komponen Konasi

Berdasarkan data pada Tabel 2, diperoleh rata-rata skor sikap peduli lingkungan pada siswa SD di Kota Ruteng sebesar 77,81 dengan kategori baik. Sedangkan rerata skor perkomponen sikapnya, yakni: 1) komponen kognisi sebesar 80,3 dengan kategori sangat baik; 2) komponen afeksi sebesar 80,05 dengan kategori baik; dan 3) komponen konasi sebesar 73,1 dengan kategori baik.

Adapun skor sikap peduli lingkungan pada siswa persekolahnya, yaitu:

1) SDK Ruteng 1 sebesar 82,07 dengan kategori sangat baik. Rincian perkomponen sikapn ya, yakni: kognisi sebesar 85,4 dengan kategori sangat baik; afeksi sebesar 85,3 dengan kategori sangat baik; dan konasi sebesar 75,5 dengan kategori baik.

2) SDK Ruteng 2 sebesar 82,07 dengan kategori sangat baik. Rincian perkomponen sikapnya, yakni: kognisi sebesar 87,3 dengan kategori sangat baik; afeksi sebesar 84,5 dengan kategori sangat baik; dan konasi sebesar 74,7 dengan kategori baik.

3) SDI Wae Ri'i sebesar 73,43 dengan kategori baik. Rincian perkomponen sikapnya, yakni: kognisi sebesar 73,5 dengan kategori baik; afeksi sebesar 74,9 dengan kategori baik; dan konasi sebesar 71,9 dengan kategori baik. 
4) SDI Karot sebesar 73,57 dengan kategori baik. Rincian perkomponen sikapnya, yakni: kognisi sebesar 74,9 dengan kategori baik; afeksi sebesar 75,5 dengan kategori baik; dan konasi sebesar 70,3 dengan kategori baik.

\section{Pembahasan}

Perserikatan Bangsa-Bangsa (PBB) melalui United Nations Environment Programme terus mengkampanyekan kesadaran lingkungan dan menekankan pentingnya kepedulian terhadap lingkungan yang menjangkau semua golongan dan kelompok usia. Melalui penetapan hari bumi yang diperingati pada 24 April tiap tahunnya, menjadi penanda meluasnya gerakan literasi lingkungan. Namun, gerakan global ini belum mendapat dukungan optimal oleh komunitas atau masyarakat tingkat lokal, khususnya di Kota Ruteng, Kabupaten Manggarai.

Permasalahan tentang lingkungan masih menjadi salah satu isu penting di Kota Ruteng. Ruteng menjadi satu dari empat kota kecil dengan nilai paling rendah pada program penilaian Adipura periode 2017 - 2018. Kementerian Lingkungan Hidup dan Kehutanan mengkategorikan Kota Ruteng sebagai salah satu kota kecil terkotor di Indonesia (Aris, 2019). Hasil ini mencerminkan rendahnya sikap peduli lingkungan pada masyarakat di Kota Ruteng.

Lembaga Pendidikan, baik dari tingkat SD hingga Perguruan Tinggi menjadi salah satu pihak yang mesti bertanggungjawab terkait permasalahan ini. Lembaga pendidikan berperan sangat vital dalam pendidikan karakter peduli lingkungan pada para siswanya. Sikap peduli lingkungan harus dibentuk sejak dini, sehingga menjadi suatu kebiasaan yang baik untuk generasi masa depan. Atas dasar itu, sikap peduli lingkungan merupakan sikap yang perlu dikembangkan pada siswa SD, sebagai calon generasi masa depan yang akan bertindak sebagai agen aktif perubahan. Sikap tersebut dibangun di atas tiga komponen penting, yaitu: kognisi (kesadaran), afeksi (perasaan), dan konasi (perilaku).

Hasil penelitian pada siswa SD Kelas IV di Kota Ruteng, diperoleh rata-rata skor sikap peduli lingkungan sebesar 77,81 dengan kategori baik. Rata-rata skor perkomponen sikapnya, yakni: komponen kognisi (kesadaran) sebesar 80,3 dengan kategori sangat baik; komponen afeksi (perasaan) sebesar 80,05 dengan kategori sangat baik; namun rendah pada komponen konasinya (perilaku) sebesar 73,1 mesikipun masih dalam kategori baik.

Sedangkan sikap peduli lingkungan pada siswa persekolahnya, menempatkan para siswa di SDK Ruteng 1 dan SDK Ruteng 2 mempunyai skor yang lebih baik dari 2 sampel SD yang lainnya. Berdasarkan pada Tabel 2, dapat diketahui para siswa kelas IV di SDK Ruteng 1 dan SDK Ruteng 2 memiliki sikap sangat baik terkait kepedulian terhadap lingkungan. Namun, sikap berkategori sangat baik ini, tidak ditunjang oleh komponen konasi (perilaku) yang hanya berkategori baik saja.

Dari ke-4 sampel SD, secara konsisten ditemukan hasil, yakni skor sikap peduli lingkungan pada komponen konasi selalu lebih rendah dari ke-2 komponen lainnya. Hal ini mengindikasikan, faktor kognisi dan afeksi tidak serta merta berpengaruh pada konasi siswa. Beberapa responden siswa berpendapat,"Jika saya melihat sampah, saya tidak mengambil sampah tersebut". Responden yang lain, dalam pernyataan tertulisnya juga memberikan pengakuan, "Saya bukan orang yang peduli akan lingkungan, karena saya pura-pura tidak melihat sampah yang berserakan". Lebih lanjut, beberapa responden juga berpendapat, "Saya bukan orang yang peduli akan lingkungan, karena saya tidak pernah membersihkan sampah di kelas". Para siswa meskipun memiliki kesadaran (kognisi) dan perasaan (afeksi) terkait permasalahan lingkungan di sekitarnya, tetapi hal tersebut belum cukup tercermin pada perilaku (konasi) kesehariannya.

Proses pembelajaran di ke-4 SD ini terutama pada tema tentang lingkungan hidup, masih cenderung dilakukan secara verbalistik, dengan lebih menekankan pada penguasaan konsep semata. Siswa memang memiliki pemahaman yang baik terhadap lingkungan, namun belum maksimal dalam mengembangkan sikap-sikap positif pada diri siswa terkait karakter peduli lingkungan. Hal ini tercermin dari skor konasi (perilaku) siswa selalu lebih rendah dari skor kognisi (kesadaran) dan afeksinya (perasaan). Padahal, peduli lingkungan merupakan sikap yang perlu dikembangkan pada siswa SD. Pembelajaran yang dikaitkan dengan sikap peduli lingkungan diharapkan mampu menyadarkan siswa agar memiliki kepedulian pada alam dan lingkungan sekitar. Hal ini sejalan dengan pendapat Kose (2011) bahwa, salah satu hasil pembelajaran yang dikaitkan dengan sikap peduli lingkungan adalah mengubah sikap siswa agar lebih positif terhadap lingkungan. Membina sikap peduli lingkungan dapat dilakukan dengan membiasakan siswa membuang sampah berdasarkan jenis sampah, merawat tanaman, menjaga kebersihan kelas dan sekolah, dan sebagainya (Yunansah \& Herlambang, 2017). 
Sekolah seharusnya menjadi media yang paling efektif dalam membangun kesadaran dan kepedulian lingkungan, tidak hanya terbatas pada penguasaan konsep saja. Oleh karena itu, guru tidak hanya dituntut sekedar mentransfer ilmu pengetahuan kepada siswa, tetapi harus kreatif dalam menggunakan strategi pembelajaran yang dapat mengaktifkan siswa dan mengembangkan sikap-sikap positif pada diri siswa. Naim (2012) berpendapat bahwa, sekolah seharusnya menyusun metode yang efektif karena peduli lingkungan merupakan salah satu karakter penting yang seyogyanya dimiliki secara luas oleh setiap orang, khususnya para siswa yang menempuh jenjang pendidikan. Susilo, dkk. (2016) juga dalam artikelnya menjelaskan bahwa, penggunaan desain pembelajaran IPA bervisi konservasi berpengaruh signifikan terhadap sikap peduli lingkungan pada siswa.

Pembelajaran yang dikaitkan dengan sikap peduli lingkungan diharapkan mampu menyadarkan siswa agar memiliki kepedulian pada alam dan lingkungan sekitar, sebagaimana yang diungkapkan oleh Zuchdi \& Darmiyati (2011). Hal ini sejalan dengan pendapat Kose (2011) bahwa, salah satu hasil pembelajaran yang dikaitkan dengan sikap peduli lingkungan adalah mengubah sikap siswa agar lebih positif terhadap lingkungan. Membina sikap peduli lingkungan dapat dilakukan dengan membiasakan siswa membuang sampah berdasarkan jenis sampah, merawat tanaman, menjaga kebersihan kelas dan sekolah, dan sebagainya (Yunansah \& Herlambang, 2017). Pembiasaan seperti ini belum secara konsisten diterapkan pada SD di Kota Ruteng.

Proses pembelajaran pada sekolah sampel penelitian juga masih monoton ceramah dan berpusat pada guru. Pendekatan secara konvensional ini tidak memberikan kesempatan bagi siswa untuk mengembangkan sikapnya, seperti peduli lingkungan. Sikap peduli lingkungan akan terinternalisasi pada diri siswa jika dipelajari menggunakan pendekatan pembelajaran yang tepat. Wanabuliandari dan Rahardjo (2017) dalam artikelnya menjelaskan bahwa, pembelajaran dengan model EJAS dengan pendekatan science edutainment dapat meningkatkan sikap peduli lingkungan. Lebih lanjut, Wanabuliandari dan Ardianti (2017) menjelaskan bahwa, pemanfaatan lingkungan sebagai sumber belajar yang dimasukkan dalam modul E-JAS edutainment dapat menanamkan karakter peduli lingkungan pada siswa. Selain itu, penggunaan media yang tepat dalam pembelajaran juga dapat berpengaruh terhadap sikap peduli lingkungan pada siswa. Hal ini sejalan dengan penelitian dari Taufiq, dkk. (2014), bahwa penggunaan media pembelajaran IPA terpadu berkarakter peduli lingkungan pada tema konservasi dengan pendekatan science edutainment, selain dapat meningkatkan hasil belajar, juga dapat menanamkan sikap peduli lingkungan pada siswa.

\section{SIMPULAN DAN SARAN}

\section{Simpulan}

Secara umum rata-rata skor sikap peduli lingkungan yang ditunjukkan siswa kelas VI SD di Kota Ruteng sebesar 77,81 dengan kategori baik. Sedangkan rerata skor sikap perkomponennya, yaitu: komponen kognisi sebesar 80,3 dengan kategori sangat baik; komponen afeksi sebesar 80,05 dengan kategori sangat baik; dan komponen konasi sebesar 73,1 dengan kategori baik.

Dari ke-4 sampel SD, secara konsisten ditemukan hasil, yakni skor sikap peduli lingkungan pada komponen konasi selalu lebih rendah dari ke-2 komponen lainnya. Hal ini mengindikasikan, faktor kognisi dan afeksi tidak serta merta berpengaruh pada konasi siswa. Para siswa meskipun memiliki kesadaran (kognisi) dan perasaan (afeksi) terkait permasalahan lingkungan di sekitarnya, tetapi hal tersebut belum cukup tercermin pada perilaku (konasi) kesehariannya.

\section{Saran}

Penelitian ini masih terbatas pada penelitian dasar guna memetakan profil sikap peduli lingkungan pada siswa SD kelas VI di Kota Ruteng. Penulis menyarankan perlunya penelitian lanjutan guna mengembangkan subject specific pedagogy (SSP) dalam membentuk dan mengembangan sikap peduli lingkungan, baik pada komponen kognisi, afeksi, dan juga konasinya.

\section{UCAPAN TERIMAKASIH}

Penulis mengucapkan terimakasih kepada:

1) Para Kepala Sekolah di SDK Ruteng 1, SDK Ruteng 3, SDI Wae Ri'i, dan SDI Karot yang telah memberikan ijin untuk melaksanakan kegiatan penelitian.

2) Para guru dan siswa kelas VI di SDK Ruteng 1, SDK Ruteng 3, SDI Wae Ri'i, dan SDI Karot yang telah berpartisipasi dalam kegiatan penelitian. 
Scholaria: Jurnal Pendidikan dan Kebudayaan, Vol. 9 No. 3, September 2019: 259-266

3) LPPM Universitas Katolik Indonesia Santu Paulus Ruteng yang telah mendanai kegiatan penelitian ini.

\section{DAFTAR PUSTAKA}

Aris. 2019. Ruteng Masuk Daftar Kota Kecil Terkotor, Ini Komentar Bupati Manggarai. Diperoleh 01 Februari 2019 dari https://www.manggaraikab.go.id/berita.php?read=625

Asmani, J. M. 2013. Buku Panduan Internalisassi Pendidikan Karakter di Sekolah. Jogjakarta: DIVA Press

Badan Pusat Statistik. 2014. Indikator Sikap Peduli Lingkungan Hidup 2014. Jakarta: Badan Pusat Statistik

Kose, S. 2011. Investigation of undergraduate students' environmental attitudes. International Electronic Journal of Environmental Education, 1 (2), 85-96.

Mahita, R. 2018. Upaya Meningkatkan Karakter Peduli Lingkungan Peserta Didik Pada Pembelajaran IPA Bervisi SETS (Science, Environment,Technology and Society) di Kelas V Sekolah Dasar. Skripsi. Program Studi PGSD, Fakultas Keguruan dan Ilmu Pendidikan, Universitas Muhammadiyah Surakarta.

Mar'at, S. 2008. Psikologi Pendidikan. Jakarta: Rineka Cipta.

Miles, B. M., Huberman, A. M. 1992. Analisis Data Qualitatif. Jakarta: UI-Press

Moleong, L. J. 2007. Metode Penelitian Kualitatif. Bandung: PT Remaja Rosdakarya.

Muslich, Masnur. 2011. Pendidikan Karakter Menjawab Tantangan Krisis Dimensional. Jakarta: Bumi Aksara

Mustofa, A. 2010. Kamus Lingkungan. Jakarta: PT Rineka Cipta

Naim, Ngainun. 2012. Character Building Optimalisasi Peran Pendidikan dalam Pengembangan Ilmu \& Pembentukan Karakter Bangsa. Jakarta: Ar-Ruzz Media

Nasution, Ruqoyah. 2016. Analisis Kemampuan Literasi Lingkungan Siswa SMA Kelas X di Samboja dalam Pembelajaran Biologi. Proceeding Biology Education Conference (ISSN: 2528-5742), 13(1), 352-358.

Rahmawati, I., Suwanda, I. M. 2015. Upaya Pembentukan Sikap Peduli Lingkungan Siswa Melalui Sekolah Adiwiyata di SMP Negeri 28 Surabaya. Kajian Moral dan Kewarganegaraan, 1 (3), 71-88.

Supardi, I. 2004. Lingkungan Hidup dan Kelestariannya. Bandung: Alumni

Susilo, H., Prasetyo, A., Ngabekti, S. 2016. Pengembangan Desain Pembelajaran IPA Bervisi Konservasi untuk Membentuk Sikap Peduli Lingkungan. Unnes Science Education Journal, 5 (1), 1065-1069. Diakses $10 \quad$ Oktober 2017 dari https://journal.unnes.ac.id/sju/index.php/usej/article/view/9562

Taufiq, M., Dewi, N., Widiyatmoko, A. 2014. Pengembangan Media Pembelajaran IPA Terpadu Berkarakter Peduli Lingkungan Tema "Konservasi" Berpendekatan Science Edutainment. Jurnal Pendidikan IPA Indonesia, 3 (2), 140-145. Diakses 1 Juni 2019 dari https://journal.unnes.ac.id/nju/index.php/jpii/article/viewFile/3113/3130

Undang-undang Republik Indonesia Nomor 32 Tahun 2009. 2009. Perlindungan dan Pengelolaan $\begin{array}{llllll}\text { Lingkungan } & \text { Hidup. } & \text { Diakses } & 10 & \text { Oktober } & 2018 \\ \end{array}$ http://175.184.234.138/p3es/uploads/unduhan/UU_32_Tahun_2009_(PPLH).pdf

Wanabuliandari, S., \& Ardianti, S. D. (2018). Pengaruh Modul E-Jas Edutainment terhadap Karakter Peduli Lingkungan dan Tanggung Jawab. Scholaria: Jurnal Pendidikan dan Kebudayaan, 8(1), 70-79. 
Analisis Sikap Peduli Lingkungan Pada Siswa Kelas VI Sekolah Dasar di Kota Ruteng

(Yosef Firman Narut, Mikael Nardi)

Wanabuliandari, S., Rahardjo, S. 2017 Peningkatan Sikap Peduli Lingkungan dan Tanggung Jawab Siswa Melalui Model EJAS dengan Pendekatan Science Edutainment. Jurnal Ilmiah Pendidikan Dasar, 4 (1), 1-7. Diakses 1 Juni 2019 dari http://jurnal.unissula.ac.id/index.php/pendas/article/view/995/775

Yunansah, H., Herlambang, Y. T. 2017. Pendidikan Berbasis Ekopedagogik dalam Menumbuhkan Kesadaran Ekologis dan Mengembangkan Karakter Siswa Sekolah Dasar. Jurnal Pendidikan Dasara EduHumaniora, 9 (1), 27- 34.

Zuchdi, Darmiyati. 2011. Pendidikan Karakter dalam Perspektif Teori dan Praktik. Yogyakarta: UNY Press 